\title{
ALUMINIUM TOXICITY AND TOLERANCE IN THREE HEATHLAND SPECIES
}

\author{
MAAIKE C. C. DE GRAAF, ROLAND BOBBINK, PETER J. M. VERBEEK and \\ JAN G. M. ROELOFS \\ Department of Ecology, Researchgroup Environmental Biology, University of Nijmegen, P.O.Box \\ 9010, 6500 GL Nijmegen, The Netherlands
}

(Received 10 November 1995; accepted 20 July 1996)

\begin{abstract}
Arnica montana and Cirsium dissectum are characteristic species of species-rich heathlands and adjacent grasslands, which declined during the last decades in the Netherlands. It has been shown in a recent field survey that the decline of $A$. montana and $C$. dissectum might be caused by soil acidification. Calluna vulgaris is not susceptible to soil acidification. It was hypothesized that increased aluminium concentrations in the soil as a result of acidifying atmospheric inputs caused the decline of $A$. montana and $C$. dissectum whereas $C$. vulgaris would not be sensitive to enhanced aluminium concentrations. We studied the effects of different $\mathrm{Al}$ :Ca-ratios and of $\mathrm{Al}$ concentrations on the development of $A$. montana, $C$. dissectum and $C$. vulgaris in nutrient solution experiments. All three species showed aluminium accumulation in the shoots related with increased aluminium concentrations in the nutrient solutions. This accumulation was correlated with a reduction in growth when plants were cultured at high Al concentrations $\left(200-500 \mu \mathrm{mol}^{-1}\right)$, in both A. montana and $C$. dissectum. In addition, indications of $\mathrm{Al}$ toxicity were observed in these plant species, e.g. poor root development, yellowish leaves and reduced contents of $\mathrm{Mg}$ and $\mathrm{P}$ in the plants. C. vulgaris did not show reduced growth or poor plant development due to high $\mathrm{Al}$ concentrations. The negative effects of aluminium in A. montana and $C$. dissectum were partly counterbalanced when plants were grown on the same $\mathrm{Al}$ concentrations but with increased Ca concentrations, resulting in lower $\mathrm{Al}$ :Ca-ratios. No effects of enhanced calcium concentrations on $C$. vulgaris have been observed.
\end{abstract}

Key words: aluminium toxicity, Arnica montana, Calluna vulgaris, Cirsium dissectum, heathland, soil acidification

\section{Introduction}

In Western Europe, soil acidification and eutrophication occur as a result of atmospheric deposition of $\mathrm{SO}_{x}, \mathrm{NO}_{y}$, and $\mathrm{NH}_{x}$. Both are a major threat to biodiversity in many (semi-) natural ecosystems (Bobbink et al., 1992). Dwarf-shrub and grassland communities occur at acidic or at slightly buffered soils in the Western-European heathland landscape, and are sensitive to both acidification and eutrophication.

As a result of enhanced nitrogen $(\mathrm{N})$ inputs, the dwarf-shrub dominated communities on acidic soils have been transformed into swards dominated by grasses (Heil and Diemont, 1983; Roelofs, 1986; Aerts and Berendse, 1988). Apart from this transition, a drastic decline in species, such as Arnica montana L. and Cirsium dissectum (L.) Hill, has been observed in Dutch heathland and adjacent grassland communities at slightly buffered soils. It has been suggested that this decline was caused by acidification as a result of $\mathrm{SO}_{x}$ deposition (Van Dam et al., 1986;

Water, Air, and Soil Pollution 98: 229-239, 1997.

(C) 1997 Kluwer Academic Publishers. Printed in the Netherlands. 
Houdijk et al., 1993; De Graaf et al., 1994). Field studies have demonstrated that these threatened plants are characteristic of soils in the cation exchange buffer range, with moderate pHs (4.5-6.0), whereas the dwarf shrubs (Calluna vulgaris (L.) Hull and Erica tetralix L.) mainly grow on acidic soils in the aluminium buffer range (Hayati and Proctor, 1990; Houdijk et al., 1993). In a field survey it was shown that $A$. montana, one of the endangered species, recently disappeared from sites which have nowadays soil $\mathrm{pH}$ values below 4.5 and with raised aluminium (Al) concentrations (Fennema, 1992).

Al toxicity after soil acidification is a widely observed phenomenon and it is generally assumed that $\mathrm{Al}^{3+}$ is the phytotoxic form (Foy et al., 1978; Ryan et al., 1994). The detrimental effects of high $\mathrm{Al}^{3+}$ concentrations have been shown particularly in forest ecosystems (e.g. Ulrich, 1983; Boxman et al., 1991; Andersson and Brunet, 1993). The effects of $\mathrm{Al}^{3+}$ can be diminished by high concentrations of divalent base cations, such as calcium (Ca) and magnesium (Mg) (Korcak, 1990; Ryan et al., 1994).

We hypothesize that increased soil Al concentrations after acidification are the major cause of the decline of the threatened plant species from these slightly buffered communities. In the present study, an analysis is given of the growth response to increasing $\mathrm{Al}$ concentrations and to different $\mathrm{Al}$ :Ca ratios in a nutrientsolution experiment. The shoot and root biomass of two seriously threatened forbs (A. montana from dry and $C$. dissectum from wet conditions) have been studied, in contrast to those of the characteristic dwarf shrub C. vulgaris. At the end of the experiment, nutrient contents of the plant material were determined and the results are discussed.

\section{Material and Methods}

\subsection{EXPERIMENTS}

Achenes of $A$. montana and $C$. dissectum were collected from a natural population in Dutch nature reserves (A. montana: Schoapedobbe, $52^{\circ} 57^{\prime} \mathrm{N}, 6^{\circ} 15^{\prime} \mathrm{E}$; $C$. dissectum: $52^{\circ} 21^{\prime} \mathrm{N}, 7^{\circ} 04^{\prime} \mathrm{E}$ ). Achenes were stored under dry and dark conditions at room temperature until the start of the experiment. Achenes were germinated in petri-dishes, on filter paper wetted with demineralised water at room temperature.

Because of the very low growth rate of Calluna vulgaris, shoot cuttings were used in stead of seedlings. These were collected in August 1993 from a natural heathland population (Schoapedobbe, $52^{\circ} 57^{\prime} \mathrm{N}, 6^{\circ} 15^{\prime} \mathrm{E}$ ) and grown on nutrient solution (without Al; see below) for 63 days in order to root. The rooted cuttings of C. vulgaris (shoot length approximately $6 \mathrm{~cm}$; root length approximately $2 \mathrm{~cm}$ ) were transferred to opaque containers (2 1), as were the seedlings of $A$. montana and $C$. dissectum (root length approximately $2 \mathrm{~cm}$ ). The nutrient solution of each container was continuously refreshed, using 101 medium per week. Aerobic conditions were 
Table I

Aluminium and calcium concentrations in the nutrient solutions (in $\mu$ mol $1^{-1}$ ). Aluminium was added as $\mathrm{AlCl}_{3}$, calcium as $\mathrm{CaCl}_{2} \cdot 2 \mathrm{H}_{2} \mathrm{O}$. In addition, $\mathrm{NaCl}$ was added in order to correct for ionic strength

\begin{tabular}{lrrr}
\hline Medium & \multicolumn{1}{c}{ Al } & Ca & $\mathrm{NaCl}$ \\
\hline A & 0 & 100 & 1500 \\
B & 50 & 100 & 600 \\
C & 100 & 100 & 300 \\
D & 200 & 100 & 150 \\
E & 500 & 100 & 0 \\
F & 100 & 1000 & 0 \\
G & 500 & 5000 & 0 \\
\hline
\end{tabular}

maintained by a continuous flow of air through the containers. Plants were grown in a climate chamber at a day/night $(14 / 10 \mathrm{~h})$ temperature of $28 / 16^{\circ} \mathrm{C}$, a light intensity of approximately $100 \mu \mathrm{E} \mathrm{m}^{-2} \mathrm{~s}^{-1}$ and with a relative humidity of 50$65 \%$. For all species, three replicates per treatment were included, except for the $50 / 100 \mathrm{Al} / \mathrm{Ca}$-treatment for $A$. montana, where $\mathrm{n}=6$. This is due to the fact that the experiment with A. montana was performed in two groups, in both of which the 50/100 Al/Ca treatment was included. No significant differences between the $50 / 100 \mathrm{Al} / \mathrm{Ca}$ treatments of both groups were found in either parameter that has been tested.

Seven $\mathrm{Al}$ and $\mathrm{Ca}$ treatments were supplied (Table I) with $\mathrm{Al}$ varying from 0 to $500 \mu \mathrm{mol}^{-1}$ and $\mathrm{Ca}$ from 100 to $5000 \mu \mathrm{mol} 1^{-1}$. Treatments with low calcium concentrations were corrected for ionic strength and chloride concentration by the addition of $\mathrm{NaCl}$ (Table I). Other nutrients were added in the following concentrations: $100 \mu \mathrm{M} \mathrm{KNO}_{3}, 100 \mu \mathrm{M} \mathrm{MgCl}_{2} \cdot 6 \mathrm{H}_{2} \mathrm{O}, 100 \mu \mathrm{M} \mathrm{Na}_{2} \mathrm{HPO}_{4} \cdot 2 \mathrm{H}_{2} \mathrm{O}$, $100 \mu \mathrm{M} \mathrm{KH}_{2} \mathrm{PO}_{4}, 70 \mu \mathrm{M}$ Fe-EDTA, $0.7 \mu \mathrm{M} \mathrm{ZnSO}_{4} \cdot 7 \mathrm{H}_{2} \mathrm{O}, 0.8 \mu \mathrm{M} \mathrm{MnCl}_{2} \cdot 4 \mathrm{H}_{2} \mathrm{O}$, $0.2 \mu \mathrm{M} \mathrm{CuSO}_{4}, 0.008 \mu \mathrm{M}\left(\mathrm{NH}_{4}\right)_{6} \mathrm{Mo}_{7} \mathrm{O}_{24} \cdot 4 \mathrm{H}_{2} \mathrm{O}, 0.8 \mu \mathrm{M} \mathrm{H}_{3} \mathrm{BO}_{3}$ and $0.3 \mu \mathrm{M}$ thiamin hydrochloride. In experiments with $C$. vulgaris, $100 \mu \mathrm{M}\left(\mathrm{NH}_{4}\right)_{2} \mathrm{SO}_{4}$ was added in addition, because of the preference of $C$. vulgaris for $\mathrm{NH}_{4}$ as a $\mathrm{N}$ source (Houdijk and Roelofs, 1993). For compensation of sulphate, only $450 \mu \mathrm{M} \mathrm{Na}_{2} \mathrm{SO}_{4}$ was added to the nutrient solutions in the Calluna-experiments, whereas the nutrient solutions in the experiments with $A$. montana and $C$. dissectum contained $500 \mu \mathrm{M}$ $\mathrm{Na}_{2} \mathrm{SO}_{4}$. The media were adjusted twice a week at $\mathrm{pH}=4.00$ by $\mathrm{HCl}$, in order to remain $\mathrm{Al}^{3+}$ in the ionic state. Never was any precipitate found in the storage or growth containers. In the plant containers, $\mathrm{pH}$ was allowed to fluctuate as result of the treatment; however, in the aluminium-containing treatments, $\mathrm{pH}$ generally remained below 4.20. In the treatments were no $\mathrm{Al}$ was added, $\mathrm{pH}$ increased to a mean value of 4.32 . 
The following numbers of plants were grown per container: A. montana: 9; $C$. dissectum: 6 ; C. vulgaris: 5 . C. dissectum and A. montana were harvested after respectively 28 and 63 days, when competition for light became obvious. Because of its low growth rate, $C$. vulgaris plants were harvested after 95 days. At harvest, shoots and roots were separated and the dry weight of the shoots and roots was measured after drying at $70{ }^{\circ} \mathrm{C}$ for $24 \mathrm{~h}$. The shoots were pooled per container for nutrient analyses as were roots, whenever enough plant material was available. Both were ground with liquid $\mathrm{N}_{2}$ and dried again $\left(70{ }^{\circ} \mathrm{C}, 24 \mathrm{~h}\right)$. The plant material was digested in $5 \mathrm{ml}$ concentrated $\mathrm{H}_{2} \mathrm{SO}_{4}$ and $2 \mathrm{ml} \mathrm{30 \%} \mathrm{H}_{2} \mathrm{O}_{2}$ (Van Dijk and Roelofs, 1988). The concentrations of $\mathrm{Al}, \mathrm{Ca}, \mathrm{Mg}$ and phosphorus (P) were determined using an ICP (type IL Plasma 200). N contents were measured colometrically with a continuous flow autoanalyser (Technicon AAII system). Due to equipment failure, we were not able to analyse all A. montana plants for N.

\subsection{STATISTICAL ANALYSIS}

Data were statistically analysed using a GLM procedure after testing for normality; multiple comparisons among pairs of means were made using the Tukey's studentized range test. Plant dry weight was log transformed before testing, in order to fit a normal distribution. All statistical analyses were performed using SAS 6.0.

\section{Results}

\subsection{SHOOT AND ROOT BIOMASS}

The dry weight of shoot and roots of A. montana decreased gradually with increasing $\mathrm{Al}$ concentration and constant $\mathrm{Ca}$ concentration $\left(100 \mu \mathrm{mol}^{-1}\right)$ in the nutrient solutions (Figure 1). The shoot dry weights were significantly lower in the 200 and $500 \mu \mathrm{mol} \mathrm{Al} 1^{-1}$ treatments, whereas root biomass was only significantly lower at $500 \mu \mathrm{mol} \mathrm{Al}{ }^{-1}$, compared with the control treatment (without $\mathrm{Al}$ ). The shoot and root biomass of $C$. dissectum increased after the addition of $50 \mu \mathrm{mol} \mathrm{Al}{ }^{-1}$ in the nutrient solution, compared with the control treatment. At higher Al concentrations (with $100 \mu \mathrm{mol} \mathrm{Ca}{ }^{-1}$ ), the shoot and root biomass decreased, however, considerably. Compared with the $50 \mu \mathrm{mol}^{-1} \mathrm{Al}$ treatment, the root dry weights were significantly lower when $200 \mu \mathrm{mol} 1^{-1} \mathrm{Al}$ or more was added to the nutrient solution. The shoot dry weight of this species decreased only significantly in the $500 \mu \mathrm{mol} \mathrm{Al}{ }^{-1}$ treatment.

The negative effects of $\mathrm{Al}$ on the dry weights of $A$. montana and C. dissectum were, although not significantly, diminished when Ca concentrations in the solutions were raised to 1000 or $5000 \mu \mathrm{mol}^{-1}$, compared with the treatment with the same $\mathrm{Al}$ concentration but low $\mathrm{Ca}$ concentration.

Plant growth of the C. vulgaris cuttings occurred during the experimental period: in all treatments new branches and leaves were formed. The dry weights of 

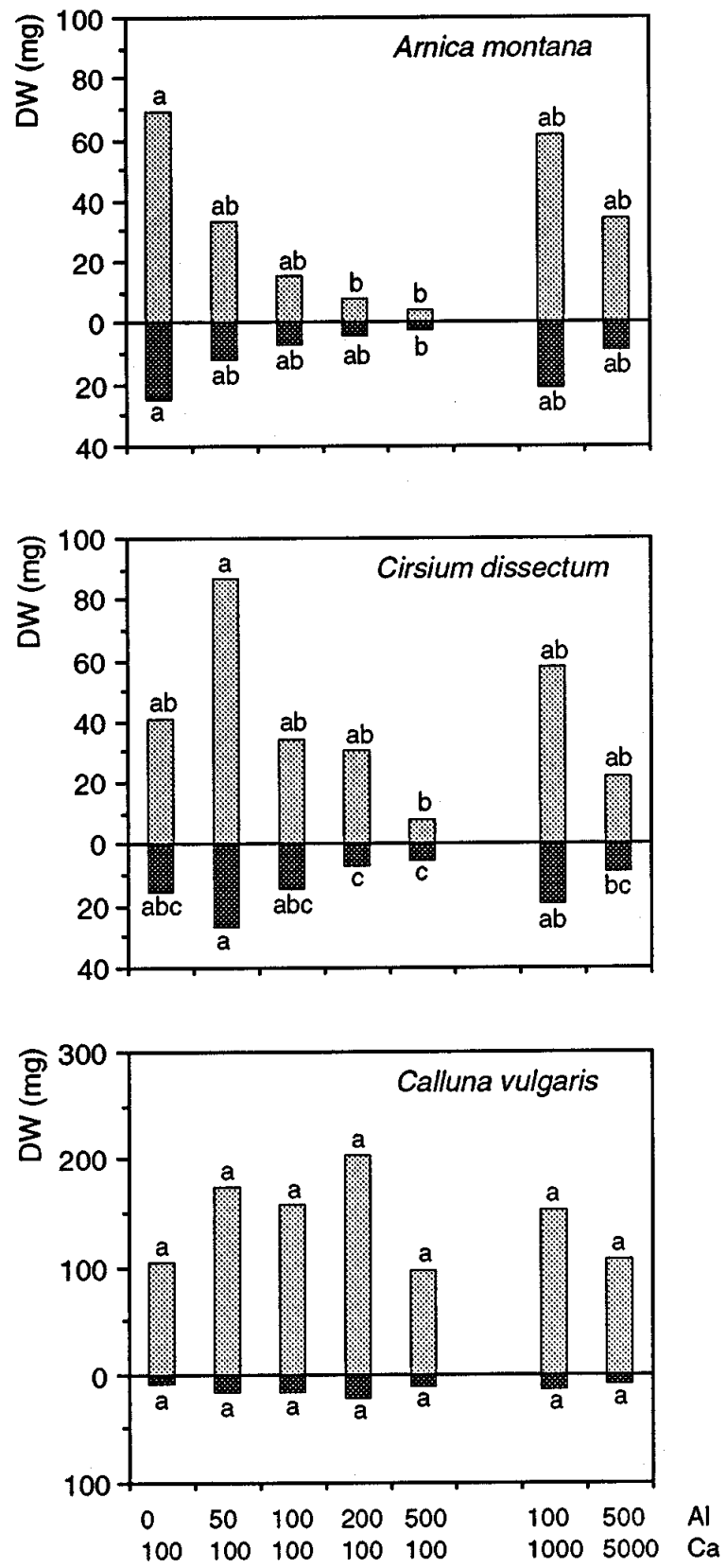

Figure 1. Mean root (dark) and shoot (light) dry weight of A. montana, C. dissectum and C. vulgaris treated with different concentrations of $\mathrm{Al}\left(0,50,100,200\right.$ or $\left.500 \mu \mathrm{mol} 1^{-1}\right)$ and $\mathrm{Ca}(100,1000$ or $\left.5000 \mu \mathrm{mol} 1^{-1}\right)$. Significant differences within species are indicated by different letters $(\mathrm{p}<0.05 ; \mathrm{N}$ $=3$ ). Significant differences in total plant dry weight follow differences in shoot dry weight for $A$. montana and $C$. vulgaris; for $C$. dissectum total dry weight was higher of plants grown on $50 \mu$ mol $1^{-1} \mathrm{Al}$ than dry weight of plants grown on 200 or $500 \mu \mathrm{mol} \mathrm{l}^{-1}$, regardless of Ca concentration. 
the shoots and roots of $C$. vulgaris were, however, not affected by the different aluminium or calcium treatments (Figure 1).

The habit of $A$. montana and $C$. dissectum was also affected by increased Al concentrations; the leaves became yellow and the root development stunted. These symptoms of reduced vitality were observed in A. montana in solutions with $50 \mu \mathrm{mol} \mathrm{Al} 1^{-1}$ or more, and in $C$. dissectum in solutions with $100 \mu \mathrm{mol} \mathrm{Al}$ $1^{-1}$ or more. Plants of both species which were grown on a nutrient solution with $100 \mu \mathrm{mol} \mathrm{Al} l^{-1}$ and $1000 \mu \mathrm{mol} \mathrm{Ca}{ }^{-1}$, did not show the symptoms of reduced

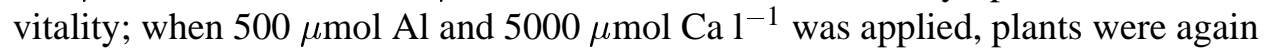
less vital. The just-described symptoms of reduced vitality were not observed in the plants of $C$. vulgaris, although the root system of this species was best developed in nutrient solutions with 100 or $200 \mu \mathrm{mol} \mathrm{All^{-1 }}$ or more, and low Ca concentrations.

\subsection{NUTRIENT CONCENTRATIONS IN THE SHOOTS AND ROOTS}

The nutrient concentrations in the roots of the three investigated heathland species were hardly influenced by the $\mathrm{Al}$ treatments, but differences in the nutrient concentrations of the shoots were observed (Table II). In all three species Al accumulated in the shoots when the $\mathrm{Al}$ concentrations in the nutrient solution increased. This increase was largest in $A$. montana-shoots, folowed by $C$. dissectum and $C$. vulgaris respectively. Shoot Al concentrations of $A$. montana and $C$. vulgaris were not

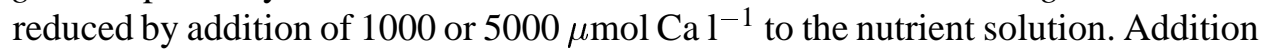
of $5000 \mu \mathrm{mol} \mathrm{Ca}^{-1}$ seemed to reduce the $\mathrm{Al}$ concentrations in the shoot material of C. dissectum, although the reduction was not significant. All three species showed higher $\mathrm{Ca}$ concentrations in the shoots when the plants were grown on nutrient solutions with high $\mathrm{Ca}$ concentrations, but no effects of increased $\mathrm{Al}$ supply on shoot $\mathrm{Ca}$ concentrations were observed. $\mathrm{Mg}$ concentrations in the shoot material of $C$. dissectum were, not significantly, reduced in the $500 \mu \mathrm{mol} \mathrm{Al} \mathrm{L}{ }^{-1}$ treatment. In the 100:1000 and 500:5000 Al:Ca treatments of $C$. dissectum, the $\mathrm{Mg}$ contents in the shoots were lower than in treatments with similar $\mathrm{Al}$ concentrations and $100 \mu \mathrm{mol} \mathrm{Ca} 1^{-1}$. Mg concentrations in the shoots of A. montana and C. vulgaris were not affected by the different treatments (Table II).

$\mathrm{P}$ concentrations of the roots of the three investigated species have not been influenced by any of the treatments. The $\mathrm{P}$ concentrations in the shoots of $C$. vulgaris were neither affected by the $\mathrm{Al}$ or $\mathrm{Ca}$ addition. The $\mathrm{P}$ concentrations in the shoots of $A$. montana, which were grown at $500 \mu \mathrm{mol} \mathrm{Al} 1^{-1}$, decreased significantly compared with the control treatment and almost independent of the applied Ca concentrations. In $C$. dissectum shoots $\mathrm{P}$ concentrations were, however, significantly higher in the $200 \mu \mathrm{mol} \mathrm{Al} \mathrm{l}^{-1}$ treatment, compared with plants which

had been supplied with 50 or $500 \mu \mathrm{mol} 1^{-1}$ Al. No effects of Al treatments on $\mathrm{N}$ concentrations in shoots or roots of the three investigated species were found. The $\mathrm{Ca}$ addition of $500 \mu \mathrm{mol}$ or $5000 \mu \mathrm{mol}^{-1}$ significantly decreased the $\mathrm{N}$ 
Table II

Mean nutrient concentration in leaf and root of A. montana, C. dissectum and C. vulgaris (in $\mu$ mol $\left.\mathrm{g}^{-1}\right)$. Significant differences between treatments are indicated by different letters $(\mathrm{p}<0.05)$

\begin{tabular}{|c|c|c|c|c|c|c|c|c|c|c|c|c|c|c|}
\hline & \multicolumn{2}{|c|}{$\begin{array}{l}\mathrm{Al}=0 \\
\mathrm{Ca}=100\end{array}$} & \multicolumn{2}{|c|}{$\begin{array}{l}\mathrm{Al}=50 \\
\mathrm{Ca}=100\end{array}$} & \multicolumn{2}{|c|}{$\begin{array}{l}\mathrm{Al}=100 \\
\mathrm{Ca}=100\end{array}$} & \multicolumn{2}{|c|}{$\begin{array}{l}\mathrm{Al}=200 \\
\mathrm{Ca}=100\end{array}$} & \multicolumn{2}{|c|}{$\begin{array}{l}\mathrm{Al}=500 \\
\mathrm{Ca}=100\end{array}$} & \multicolumn{2}{|c|}{$\begin{array}{l}\mathrm{Al}=100 \\
\mathrm{Ca}=1000\end{array}$} & \multicolumn{2}{|c|}{$\begin{array}{l}\mathrm{Al}=500 \\
\mathrm{Ca}=5000\end{array}$} \\
\hline \multicolumn{15}{|c|}{ A. montana, shoot } \\
\hline $\mathrm{Al}$ & 3.7 & $\mathrm{a}$ & 56 & $a b$ & 96 & $a b$ & 148 & $a b$ & 234 & $\mathrm{~b}$ & 75 & $a b$ & 207 & $a b$ \\
\hline $\mathrm{Ca}$ & 125 & $\mathrm{a}$ & 109 & $\mathrm{a}$ & 84 & $\mathrm{a}$ & 72 & $\mathrm{a}$ & 83 & $\mathrm{a}$ & 463 & $\mathrm{~b}$ & 775 & $\mathrm{c}$ \\
\hline $\mathrm{Mg}$ & 121 & $\mathrm{a}$ & 66 & $\mathrm{a}$ & 96 & $\mathrm{a}$ & 83 & $\mathrm{a}$ & 75 & $\mathrm{a}$ & 74 & $\mathrm{a}$ & 204 & $\mathrm{a}$ \\
\hline $\mathrm{P}$ & 621 & $\mathrm{ac}$ & 665 & $\mathrm{a}$ & 672 & $\mathrm{a}$ & 493 & $a b$ & 231 & $\mathrm{~b}$ & 462 & $a b$ & 291 & $\mathrm{bc}$ \\
\hline $\mathrm{N}$ & $*$ & & 1786 & $\mathrm{a}$ & * & & $*$ & & $*$ & & 1759 & $\mathrm{a}$ & 1231 & $\mathrm{~b}$ \\
\hline $\mathrm{n}$ & 3 & & 6 & & 3 & & 3 & & 3 & & 3 & & 2 & \\
\hline \multicolumn{15}{|c|}{ C. dissectum, shoot } \\
\hline $\mathrm{Al}$ & $<0.2$ & $\mathrm{a}$ & $<0.2$ & $\mathrm{a}$ & 24 & $\mathrm{ac}$ & 181 & $\mathrm{~b}$ & 112 & bcd & 25 & $\mathrm{ad}$ & 23 & ad \\
\hline $\mathrm{Ca}$ & 239 & $\mathrm{a}$ & 227 & $\mathrm{a}$ & 237 & $\mathrm{a}$ & 295 & a & 123 & $\mathrm{a}$ & 661 & $\mathrm{~b}$ & 970 & $\mathrm{~b}$ \\
\hline $\mathrm{Mg}$ & 212 & $a b$ & 203 & $a b$ & 204 & $a b$ & 290 & $\mathrm{~b}$ & 88 & $\mathrm{ac}$ & 80 & $\mathrm{ac}$ & 17 & $\mathrm{c}$ \\
\hline $\mathrm{P}$ & 178 & $a b$ & 154 & $\mathrm{a}$ & 206 & $a b$ & 379 & $\mathrm{~b}$ & 136 & $\mathrm{a}$ & 195 & $a b$ & 70 & $\mathrm{a}$ \\
\hline $\mathrm{N}$ & 937 & $\mathrm{a}$ & 711 & $\mathrm{a}$ & 1409 & $\mathrm{a}$ & 736 & $\mathrm{a}$ & 442 & $\mathrm{a}$ & 589 & $\mathrm{a}$ & 223 & $\mathrm{a}$ \\
\hline $\mathrm{n}$ & 2 & & 3 & & 2 & & 3 & & 3 & & 3 & & 3 & \\
\hline \multicolumn{15}{|c|}{ C. vulgaris, shoot } \\
\hline $\mathrm{Al}$ & 6 & $\mathrm{a}$ & 26 & $a b$ & 28 & $a b$ & 43 & $a b$ & 84 & $\mathrm{~b}$ & 24 & $a b$ & 46 & $\mathrm{ab}$ \\
\hline $\mathrm{Ca}$ & 70 & $a b$ & 67 & $\mathrm{a}$ & 84 & $a b$ & 63 & a & 63 & a & 243 & $a b$ & 293 & $\mathrm{~b}$ \\
\hline $\mathrm{Mg}$ & 55 & $\mathrm{a}$ & 67 & $\mathrm{a}$ & 79 & $\mathrm{a}$ & 70 & $\mathrm{a}$ & 62 & $\mathrm{a}$ & 67 & $\mathrm{a}$ & 48 & $\mathrm{a}$ \\
\hline $\mathrm{P}$ & 99 & $\mathrm{a}$ & 142 & $\mathrm{a}$ & 137 & $\mathrm{a}$ & 128 & $\mathrm{a}$ & 117 & $\mathrm{a}$ & 115 & $\mathrm{a}$ & 109 & $\mathrm{a}$ \\
\hline $\mathrm{N}$ & 973 & $\mathrm{a}$ & 1149 & $\mathrm{a}$ & 1234 & $\mathrm{a}$ & 1272 & $\mathrm{a}$ & 1216 & $\mathrm{a}$ & 1122 & $\mathrm{a}$ & 1391 & $\mathrm{a}$ \\
\hline $\mathrm{n}$ & 3 & & 3 & & 2 & & 3 & & 3 & & 3 & & 2 & \\
\hline \multicolumn{15}{|c|}{ A. montana, root } \\
\hline $\mathrm{Al}$ & 90 & $\mathrm{a}$ & 218 & $\mathrm{a}$ & 239 & $\mathrm{a}$ & 224 & $\mathrm{a}$ & 273 & $\mathrm{a}$ & 319 & $\mathrm{a}$ & 223 & $\mathrm{a}$ \\
\hline $\mathrm{Ca}$ & 343 & $\mathrm{a}$ & 94 & $\mathrm{a}$ & 66 & $\mathrm{a}$ & 111 & $\mathrm{a}$ & 147 & $\mathrm{a}$ & 108 & $\mathrm{a}$ & 21 & $\mathrm{a}$ \\
\hline $\mathrm{Mg}$ & 124 & $\mathrm{a}$ & 214 & $\mathrm{a}$ & 77 & $\mathrm{a}$ & 99 & $\mathrm{a}$ & 162 & $\mathrm{a}$ & 318 & $\mathrm{a}$ & 214 & $\mathrm{a}$ \\
\hline $\mathrm{P}$ & 709 & $\mathrm{a}$ & 924 & $\mathrm{a}$ & 758 & $\mathrm{a}$ & 778 & $\mathrm{a}$ & 945 & $\mathrm{a}$ & 636 & $\mathrm{a}$ & 218 & $\mathrm{a}$ \\
\hline $\mathrm{N}$ & $*$ & & 1532 & $\mathrm{a}$ & * & & * & & * & & 1429 & $a b$ & 806 & b \\
\hline $\mathrm{n}$ & 3 & & 6 & & 3 & & 3 & & 3 & & 3 & & 1 & \\
\hline \multicolumn{15}{|c|}{ C. dissectum, root } \\
\hline $\mathrm{Al}$ & $<0.2$ & a & 60 & $\mathrm{a}$ & 163 & $\mathrm{a}$ & 189 & $\mathrm{a}$ & 144 & $\mathrm{a}$ & 121 & $\mathrm{a}$ & 81 & $\mathrm{a}$ \\
\hline $\mathrm{Ca}$ & 65 & a & 104 & $\mathrm{a}$ & 32 & $\mathrm{a}$ & 23 & $\mathrm{a}$ & 36 & $\mathrm{a}$ & 58 & $\mathrm{a}$ & 58 & $\mathrm{a}$ \\
\hline $\mathrm{Mg}$ & 31 & $\mathrm{a}$ & 47 & $\mathrm{a}$ & 33 & $\mathrm{a}$ & 24 & $\mathrm{a}$ & 11 & $\mathrm{a}$ & 34 & $\mathrm{a}$ & 0 & $\mathrm{a}$ \\
\hline $\mathrm{P}$ & 165 & $\mathrm{a}$ & 268 & $\mathrm{a}$ & 499 & $\mathrm{a}$ & 472 & $\mathrm{a}$ & 182 & $\mathrm{a}$ & 452 & $\mathrm{a}$ & 187 & $\mathrm{a}$ \\
\hline $\mathrm{N}$ & 493 & $\mathrm{a}$ & 610 & $\mathrm{a}$ & 536 & $\mathrm{a}$ & 339 & $\mathrm{a}$ & 55 & $\mathrm{a}$ & 475 & $\mathrm{a}$ & 105 & $\mathrm{a}$ \\
\hline $\mathrm{n}$ & 2 & & 1 & & 2 & & 3 & & 3 & & 3 & & 3 & \\
\hline
\end{tabular}

(table continues on next page) 
Table II

Continued.

\begin{tabular}{|c|c|c|c|c|c|c|c|c|c|c|c|c|c|c|}
\hline & \multicolumn{2}{|c|}{$\mathrm{Ca}=100$} & \multicolumn{2}{|c|}{$\begin{array}{l}\mathrm{Al}=50 \\
\mathrm{Ca}=100\end{array}$} & \multicolumn{2}{|c|}{$\begin{array}{l}\mathrm{Al}=100 \\
\mathrm{Ca}=100\end{array}$} & \multicolumn{2}{|c|}{$\begin{array}{l}\mathrm{Al}=200 \\
\mathrm{Ca}=100\end{array}$} & \multicolumn{2}{|c|}{$\begin{array}{l}\mathrm{Al}=500 \\
\mathrm{Ca}=100\end{array}$} & \multicolumn{2}{|c|}{$\begin{array}{l}\mathrm{Al}=100 \\
\mathrm{Ca}=1000\end{array}$} & \multicolumn{2}{|c|}{$\begin{array}{l}\mathrm{Al}=500 \\
\mathrm{Ca}=5000\end{array}$} \\
\hline \multicolumn{15}{|c|}{ C. vulgaris, root } \\
\hline $\mathrm{Al}$ & 15 & $\mathrm{a}$ & 319 & $a b$ & 263 & $a b$ & 256 & $a b$ & 412 & $\mathrm{~b}$ & 272 & $a b$ & 157 & $\mathrm{ab}$ \\
\hline $\mathrm{Ca}$ & 11 & a & 11 & $\mathrm{a}$ & 40 & $\mathrm{a}$ & 21 & $\mathrm{a}$ & 41 & $\mathrm{a}$ & 28 & $\mathrm{a}$ & 20 & $\mathrm{a}$ \\
\hline $\mathrm{Mg}$ & 60 & $\mathrm{a}$ & 24 & $\mathrm{a}$ & 72 & $\mathrm{a}$ & 52 & $\mathrm{a}$ & 63 & $\mathrm{a}$ & 73 & a & 34 & a \\
\hline $\mathrm{P}$ & 189 & $\mathrm{a}$ & 308 & $\mathrm{a}$ & 374 & $\mathrm{a}$ & 406 & $\mathrm{a}$ & 521 & $\mathrm{a}$ & 438 & $\mathrm{a}$ & 225 & $\mathrm{a}$ \\
\hline $\mathrm{N}$ & 1965 & a & 1106 & $\mathrm{a}$ & 1752 & $\mathrm{a}$ & 1759 & $\mathrm{a}$ & 2396 & $\mathrm{a}$ & 1748 & $\mathrm{a}$ & 1129 & $\mathrm{a}$ \\
\hline $\mathrm{n}$ & 2 & & 2 & & 2 & & 3 & & 3 & & 2 & & 1 & \\
\hline
\end{tabular}

$\mathrm{n}=$ Number of replicates, $*=$ Not determined.

concentrations in the leaves of $A$. montana (Table II), but due to equipment failure we were unable to determine $\mathrm{N}$ concentrations of the shoots in all treatments.

\section{Discussion}

In many studies the toxicity of $\mathrm{Al}$ for plant species has been investigated on water culture. In order to relate the results to the field situation, it is essential that the nutrient solutions which are used resemble the soil solution as best as possible (Andersson and Brunet 1993; Sverdrup and Warfvinge, 1993; Falkengren-Grerup, 1994). In heathland ecosystems, nutrient concentrations of the soil are very low. The nutrient concentrations that we have used in this experiment are in good agreement with field measurements, except for $\mathrm{P}$ and $\mathrm{K}$ (data not shown). These were somewhat higher in the nutrient solution than in the field (Table II, Matzner and Ulrich, 1980; Hayati and Proctor, 1990; Houdijk et al., 1993; De Graaf et al., 1994).

The growth of $A$. montana and $C$. dissectum was negatively affected by $\mathrm{Al}$ concentrations of $100 \mu \mathrm{mol} 1^{-1}$ and more, whereas growth of the dwarf-shrub $C$. vulgaris was not affected at all. Symptoms of reduced vitality, e.g. stunted root growth and changes in chemical plant composition, have also been observed with increasing $\mathrm{Al}$ concentrations for $A$. montana and $C$. dissectum. In A. montana, the most Al-sensitive species, root development was already influenced at $50 \mu \mathrm{mol} \mathrm{Al}$ $1^{-1}$. Stimulation of plant growth by low $\mathrm{Al}$ concentrations, as in $C$. dissectum in this experiment, has been observed for more species (Foy, 1978). Hackett (1965) showed that growth of Deschampsia flexuosa, a characteristic grass species of acidic habitats, is also stimulated by low $\mathrm{Al}$ concentrations.

Our results concerning the effects of $\mathrm{Al}$ on $A$. montana do not agree with those found by Pegtel (1987) and Kroeze et al. (1989). They concluded that the growth of A. montana on water culture was not influenced by $\mathrm{Al}$, not even at $\mathrm{Al}$ concentrations of almost $3000 \mu \mathrm{mol}^{-1}$. However, already at intermediate Al concentrations Pegtel 
(1987) observed reduced root elongation, a reduction in fine-branching of the roots, yellowish-green leaves and the development of necrotic spots on the leaves. This indicates that plants are affected by the treatment; particularly the mentioned root morphology is characteristic of Al toxicity (Foy et al., 1978). The difference in the sensitiveness of $A$. montana to $\mathrm{Al}$ is most likely caused by the very high nutrient concentrations (especially N: $4000 \mu \mathrm{mol} \mathrm{l}^{-1}$ and $\mathrm{K}: 2330 \mu \mathrm{mol} \mathrm{l}^{-1}$ ) in the media used by Pegtel (1987) and Kroeze et al. (1989) and the lower, more realistic concentrations used in this experiment ( $\mathrm{N}: 100 \mu \mathrm{mol} \mathrm{l}^{-1}, \mathrm{~K}: 600 \mu \mathrm{mol} \mathrm{l}^{-1}$ ). The high nutrient concentrations in solutions might enable sufficient nutrient uptake by plants, even when root vitality and nutrient uptake capacity are reduced by $\mathrm{Al}$ (Foy et al., 1978).

Chemical composition of plants differs between roots and shoots and between species and can be influenced by environmental stresses. A commonly observed phenomenon of high $\mathrm{Al}$ concentrations in soil or nutrient solutions is the accumulation of $\mathrm{Al}$ in the plant (Foy et al., 1978). In this study, $\mathrm{Al}$ concentrations in all three heathland species clearly increased with increasing $\mathrm{Al}$ concentrations in the nutrient solution (Table II). This increase in Al concentrations in the shoots correlated with the decrease in plant biomass of A. montana and partly with the decrease in biomass of $C$. dissectum. Growth was not reduced in $C$. vulgaris. This species thus seems to resist high concentrations of $\mathrm{Al}$ in the shoot, whereas the other investigated species are affected by these $\mathrm{Al}$ concentrations. High $\mathrm{Al}$ concentrations in nutrient solutions are known to influence the uptake of minerals; particularly the uptake of the divalent cations $\mathrm{Ca}$ and $\mathrm{Mg}$ is often disturbed by $\mathrm{Al}$ (Foy et al., 1978, for a recent review see Delhaize and Ryan, 1995). However, none of the three heathland species showed significant decreases in Ca concentrations in roots or shoots, while the $\mathrm{Mg}$ concentration was only decreased in the highest $\mathrm{Al}$ treatment in the shoots of $C$. dissectum (Table II). This strongly suggests that the detrimental effects of $\mathrm{Al}$ in this study are not primarily caused by reduced cation uptake.

$\mathrm{N}$ and $\mathrm{P}$ are the main growth limiting factors in nutrient-poor habitats. $\mathrm{Al}$ significantly reduced plant $\mathrm{P}$ concentrations in the two species sensitive to $\mathrm{Al}$ (Table II). P deficiencies sometimes appear as a result of Al toxicity (Foy, 1978). It is, however, unlikely that the observed effects of $\mathrm{Al}$ on plant growth in this experiment are caused by $\mathrm{P}$ deficiency, because even in the highest $\mathrm{Al}$ treatment $\mathrm{P}$ concentrations in the plant are considerably higher than those of natural populations (Hayati and Proctor, 1990; Pegtel, 1994).

Negative effects of $\mathrm{Al}$ on growth and plant vitality were partly ameliorated in A. montana and, to a lesser degree, $C$. dissectum by high $\mathrm{Ca}$ concentrations. The beneficial effects of $\mathrm{Ca}$ on $\mathrm{Al}$ toxicity in plants have been recognized for a long time, although the mechanism by which $\mathrm{Ca}$ reduces Al toxicity is not yet fully understood (Rengel, 1992; Kinraide et al., 1994; Ryan et al., 1994). Recent research by Ryan et al. (1994) shows that Ca primarily reduces the negative effects of $\mathrm{Al}$ on root elongation, not on Ca uptake. Despite this, the Ca concentrations in the 
above-ground parts of $C$. dissectum and A. montana are significantly raised by the addition of 1000 or $5000 \mu \mathrm{mol} \mathrm{Ca} \mathrm{^{-1 }}$ to the nutrient solution in this experiment. A correlation between $\mathrm{Ca}$ in the soil solution and plant uptake was also found in the field for C. dissectum by Hayati and Proctor (1990). This increase in Ca concentrations in A. montana and $C$. dissectum correlated partly with the increase in biomass production and improved vitality of the plants. Still, the detrimental effects of $\mathrm{Al}$ cannot be fully reversed by high Ca concentrations (Figure 1), indicating that high concentrations of $\mathrm{Al}$ are toxic themselves to these two species.

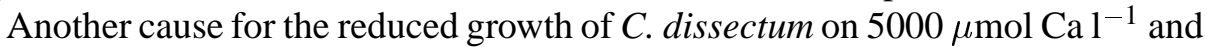
$500 \mu \mathrm{mol} \mathrm{Al} 1^{-1}$ might be this very high Ca concentrations in the nutrient solution, which reduce $\mathrm{Mg}$ concentrations in the shoots. Schimansky (1991) reported a similar negative effect of high Ca concentrations in the nutrient solutions, which added to the effects of $\mathrm{Al}$ toxicity.

\subsection{ECOLOGICAL IMPLICATIONS}

Plants in acidic habitats have to deal with extreme soil properties: high hydrogen and aluminium concentrations, low calcium concentrations, relatively high manganese and ferrous concentrations and high ammonium to nitrate ratios (Runge and Rode, 1991). The results of this experiment reveal the sensitivity of $A$. montana and $C$. dissectum to $\mathrm{Al}$ concentrations $>100 \mu \mathrm{mol} \mathrm{l}^{-1}$. This could be one of the major causes for the recent decline of these species. The observed sensitivity is in good agreement with the results of pot experiments of Heijne (1995) and with those of a field survey by Fennema (1992) on A. montana. The latter showed that sites from which $A$. montana had recently became extinct, had higher exchangeable Al concentrations than sites where the species was still present. Since all the tested plants developed well in our experiments at $\mathrm{pH}=4.0$, when they were grown on nutrient solutions containing $50 \mu \mathrm{mol} 1^{-1} \mathrm{Al}$ or less, we assume that toxicity of hydrogen ions is not important for A. montana, C. dissectum or C. vulgaris.

Our results indicate furthermore that low $\mathrm{Ca}$ concentrations in soil might be a problem for A. montana and C. dissectum. Both species have distinctly higher $\mathrm{Ca}$ concentrations in the shoot than C. vulgaris (Table 1, Hayati and Proctor, 1990; Pegtel, 1994). Again, these findings confirm the limited adaptation of A. montana and $C$. dissectum to acidifying conditions, where $C$. vulgaris is more tolerant to the acidic conditions.

\section{Acknowledgements}

The authors thank Professor Dr. C. den Hartog and Dr. A.W. Boxman for critical reading the manuscript. We thank G. Hendriksen, F. Jansen, T. Lycklama à Nijeholt and N. Keultjes for their practical assistence and M. Regenboog for his help with the figures. This study was financed by the Dutch Ministry of Agriculture, Nature Conservation and Fishery. 


\section{References}

Aerts, R.: 1993, in R. Aerts and G. W. Heil (eds.) Heathlands: Patterns and Processes in a Changing Environment, Dordrecht, Kluwer Academic Publishers.

Aerts, R. and Berendse, F.: 1988, Vegetatio 76, 63.

Andersson, M. E. and Brunet, J.: 1993, Plant Soil 153, 243.

Bobbink, R., Boxman, D., Fremstad, E., Heil, G., Houdijk, A. and Roelofs, J.: 1992, Critical Loads for Nitrogen Eutrophication of Terrestrial and Wetland Ecosystems Based Upon Changes in Vegetation and Fauna. Nordic Council of Ministers, Copenhagen, Miljörapport, 41, 111-159.

Boxman, A. W., Krabbendam, H., Bellemakers, M. J. S. and Roelofs, J. G. M.: 1991, Environ. Pollut. 73, 119.

De Graaf, M. C. C., Verbeek, P. J. M., Cals, M. J. R. and Roelofs, J. G. M.: 1994, Effectgerichte maatregelen tegen verzuring en eutrofiëring van matig mineraalrijke heide en schraallanden. University of Nijmegen, The Netherlands.

Delhaize, E. and Ryan, P. R.: 1995, Plant Physiol. 107, 315.

Dueck, T. A. and Elderson, J.: 1992, New Phytol. 122, 507.

Falkengren-Grerup, U.: 1994, J. Appl. Ecol. 31, 182.

Fennema, F.: 1992, Water, Air, and Soil Pollut. 62, 325.

Foy, C. D., Chaney, R. L. and White, M. C.: 1978, Annu. Rev. Plant Physio. 29, 511.

Hackett, C.: 1965, J. Ecol. 35, 299.

Hayati, A. A. and Proctor, M. C. F.: 1990, J. Ecol. 78, 134.

Heil, G. W. and Diemont, W. H.: 1983, Vegetatio 53, 113.

Heijne, B., Van Dam, D., Heil, G. W. and Bobbink, R.: 1995, in Effects of Acid Rain on VesiculairArbuscular Mycorrhiza of Herbaceous Plants in Dry Heathland, PhD-Thesis, University of Utrecht, The Netherlands.

Houdijk, A. L. M. F. and Roelofs, J. G. M.: 1993, in Atmospheric Ammonium Deposition and the Nutritional Balance of Terrestrial Ecosystems, PhD-Thesis, University of Nijmegen, The Netherlands.

Houdijk, A. L. F. M., Verbeek, P. J. M., Van Dijk, H. F. G. and Roelofs, J. G. M.: 1993, Plant Soil 148, 137.

Kinraide, T. B., Ryan, P. R. and Kochian, L. V.: 1994, Planta 192, 104.

Korcak, R. F.: 1990, in M. L. van Beusichem (ed.), Plant Nutrition - Physiology and Applications, Dordrecht, Kluwer Academic Publishers.

Kroeze, C., Pegtel, D. M. and Blom, C. J. C.: 1989, Acta Bot. Neerl. 38, 165.

Matzner, E.: 1980, Untersuchungen zum Elementhaushalt eines Heide-Ökosystems (Calluna vulgaris) in Nordwestdeutschland, Thesis, University of Göttingen, Germany.

Matzner, E. and Ulrich, B.: 1980, Z. Pflanzenernäerh. Bodenkd. 143, 666.

Pegtel, D. M.: 1987, Plant Soil 102, 85.

Pegtel, D. M.: 1994, Vegetatio 114, 109.

Rengel, Z.: 1992, New Phytol. 121, 499.

Roelofs, J. G. M.: 1986, Experientia 42, 372.

Runge, M. and Rode, M. W.: 1991, in B. Ulrich and M. E. Sumner (eds.), Soil acidity, Berlin, Springer Verlag.

Ryan, P. R., Kinraide, T. B. and Kochian, L. V.: 1994, Planta 192, 98.

Schimansky, C.: 1991, Z. Pflanzenernäerh. Bodenkd. 154, 195.

Sverdrup, H. and Warfvinge, P.: 1993, The Effect of Soil Acidification on the Growth of Trees, Grass and Herbs as Expressed by the $(\mathrm{Ca}+\mathrm{Mg}+\mathrm{K}) / \mathrm{Al}$ Ratio, Reports in ecology and environmental engineering, Lund.

Ulrich, B.: 1983, in Ulrich, B. and Pankrath, J. (eds.) Effects of Accumulation of Air Pollutants in Forest Ecosystems, Reidel Publ. Comp., Dordrecht, The Netherlands.

Van Dam, D., Van Dobben, H. F., Ter Braak, C. F. J. and De Wit, T.: 1986, Vegetatio 65, 47.

Van Dijk, H. F. G. and Roelofs, J. G. M.: 1988, Physiol. Plant. 73, 494. 